\title{
TECCIENCIA
}

\section{Operations Research: from Strategy to Meaningful Learning}

\section{Investigación de Operaciones: de Estrategia a Aprendizaje Significativo}

\author{
Eilen Lorena Perez Montero ${ }^{1 *}$, Jorge Bernardo Ramírez Zarta ${ }^{1}$ \\ ${ }^{1}$ Corporaciòn Universitaria del Huila, Neiva, Colombia
}

\begin{abstract}
This paper examines the use of information communication technology (ICT) for meaningful learning in the undergrad course of Operation Research taken in the fourth year of Industrial Engineering at University Corporation of Huila, CORHUILA. Over the past year, students that took Operation Research showed difficulty in understanding the concepts, answering tests which reflected on the final grade. Therefore, it was necessary to examine the application of ICT tools in the classroom. To show the effectiveness of the proposed methodology, it was designed a quasi-experimental research with a sample of 68 students distributed in two groups. The Control group was thought using the traditional methodology; whereas the Experimental group had access to ICT tools for learning. The results showed a significant relationship between the academic success of the Experimental group and the ICT tools applied; moreover, better grading compared to the Control group.
\end{abstract}

Keywords: Meaningful learning, Operations Research, ICT.

\section{Resumen}

Este artículo examina el uso de Tecnologías de Información y Comunicación (TIC) para el aprendizaje significativo en el curso de pregrado de Investigación de Operaciones del cuarto año de Ingeniería Industrial en CORHUILA. Durante los años anteriores, los estudiantes que tomaron el curso mostraron dificultades entendiendo conceptos y respondiendo pruebas, lo cual se vio reflejado en la nota final. Por lo tanto, es necesario examinar la aplicación de herramientas TIC en el aula de clase. Para mostrar la efectividad de la metodología propuesta, se diseñó una propuesta de investigación semi-experimental con una muestra de 68 estudiantes distribuidos en dos grupos. El grupo de control fue pensado usado metodología tradicional, mientras que el grupo experimental tuvo acceso a herramientas TIC para aprendizaje. El resultado muestra una relación significativa entre el éxito académico del grupo experimental y las herramientas TIC utilizadas, y unas notas mejores comparadas con el grupo de control.

Palabras Clave: Aprendizaje Significativo, Investigación de Operaciones, TIC.

\section{Introduction}

The course of Operations Research allows the student to design and implement mathematical models, tending a successful decision-making process in the optimization of resources and seeking economic growth of organizations [1]

In the Operations Research course, the concept of Network Modelling is essential to generate alternative solutions to problems that lead to minimizing costs and optimizing resources.

*Corresponding Author.

E-mail: eilen.perez@corhuila.edu.co
In this course, a network is understood as a relation of two types of elements called nodes and arcs, so the arc has a node at each of its ends. Nodes and arcs interactions can symbolize trajectories from one place to another, up to the sequence in which the activities of a project must be executed for its realization.

According to Pearl [1988], the networks are used in different applications such as medicine, science and economics. They provide a compact way of representing knowledge and flexible methods of reasoning.

How to cite: Perez, E., Ramirez, J., Operations Research: from Strategy to Meaningful Learning, TECCIENCIA, Vol. 14 No. 26, 9 14, 2019

DOI: http://dx.doi.org/10.18180/tecciencia.2019.26.2 


\section{TECCIENCIA}

Table 1 Use of ICT for teachers that guide operations research course.

\begin{tabular}{lllll}
\hline Instructor & $\begin{array}{l}\text { Solver } \\
\text { Microsoft } \\
\text { Excel }\end{array}$ & Promodel & $\begin{array}{l}\text { Win } \\
\text { QSB }\end{array}$ & Project \\
\hline Instructor 1 & $\mathrm{X}$ & $\mathrm{X}$ & & $\mathrm{X}$ \\
\hline Instructor 2 & $\mathrm{X}$ & & $\mathrm{X}$ & \\
\hline Instructor 3 & & & $\mathrm{X}$ & \\
\hline Instructor 4 & & & & \\
\hline Instructor 5 & & $\mathrm{X}$ & $\mathrm{X}$ & \\
\hline Instructor 6 & & & \\
\hline
\end{tabular}

This method is based on probabilistic theories - capable of predicting the value of unobserved variables and explaining the observed ones [2]

Based on an analysis carried out in the last academic year of the Operations Research course, it can be seen unfavorable results in $44 \%$ of activities evaluated in the Network Modelling topic.

Moreover, it has been shown that not all instructors make appropriate use of the Information and Communication Technologies (ICT) as well as the specialized software for the course. This statement is based on a survey of 6 teachers shown Table 1, which indicates that two out of six instructors do not use any software; whereas, only three teachers use some of the required software.

In relation to what has been mentioned above, it is clear that the introduction of Information and Communication Technologies is in most cases produced with difficulty because of the professors' lack of interest to face a generational change. Likewise, the trend in traditional methodology is reinforced in the Operations Research course, where students receive the contents that are transmitted by the professor, and a given notion of discipline makes the students more receptive of the information.

According to [3] there must be a strong connection between innovation and ICT in the education system, aimed at a real methodology renewal process which influences learning, and performance of students. This makes it necessary for professors to acquire abilities in the area of information technology and continuous training, which widens the range of strategies to improve teaching performance [4].

However, the integration of these technologies in the basic processes of universities in Colombia, is shown every day as an innovative tool in the transmission of new knowledge and as responses to the demands of knowledge societies and changes in today's society.
Table 2 Displays corresponding to each group.

\begin{tabular}{llll}
\hline & $\begin{array}{l}\text { Number of } \\
\text { students }\end{array}$ & Women & Men \\
\hline $\begin{array}{l}\text { Group 1: } \\
\text { Without } \\
\text { meaningful } \\
\text { learning } \\
\text { strategy }\end{array}$ & 34 & 10 & 24 \\
\hline $\begin{array}{l}\text { Group 2: } \\
\text { with } \\
\text { meaningful }\end{array}$ & 34 & 13 & 21 \\
learning \\
strategy
\end{tabular}

Such is the case of the Universidad de los Andes, where through its postgraduate academic programs, researches and projects, pedagogical practices incorporate the support of educational innovations with ICTs with learning environments that strengthen teaching and learning processes [5].

Other Universities such as Universidad Javeriana, Universidad Abierta a Distancia, position ICTs as tools for stimulating high-level cognitive processes in actions of analysis, synthesis and evaluation of knowledge, where students are not passive entities to the process, but active to it, managing to create artefacts and integrate them with different languages (audio, video, image, text, multimedia).

Such education practices raise these questions: how meaningful is the students' learning? and: How can one offer to teach proposals that can be more satisfying and pleasant?. Meaningful learning makes it possible for students to connect with the world, to give solutions to problems of different kinds, to renew knowledge and to find a purpose for learning and for what is being done [6].

David Paul Ausbel [7] states that meaningful learning implies that students are able to make connections among concepts and to give them meaning from the conceptual structure that they have. [8], there must be two fundamental conditions: Attitude to learn in a meaningful way and the presentation of a potentially meaningful material.

In view of the above, selection, organization and information transformation activities were designed with the previous knowledge, including tools that are provided by information and communication technologies (ICT) in order to generate pleasing and innovative experiences which can boost analysis, thought, interaction and consolidation of knowledge, where students are able to lead their own process [9] [10]. 
Table 3 Analysis of Pretest - Pretest stockings

\begin{tabular}{llllll}
\hline Groups & Median & $\mathrm{N}$ & Dev & Min & Max \\
\hline $\begin{array}{l}\text { Without } \\
\text { meaningful } \\
\text { learning } \\
\text { strategy }\end{array}$ & 0.76 & 34 & 0.65 & 0 & 2 \\
\hline $\begin{array}{l}\text { With } \\
\text { meaningful } \\
\text { learning } \\
\text { strategy }\end{array}$ & 0.68 & 34 & 0.73 & 0 & 2 \\
\hline Total & 0.72 & 68 & 0.69 & 0 & 2 \\
\hline & & & & & \\
\hline
\end{tabular}

\section{Methodology of Research}

The proposal was incorporating a quasi-experimental design with two (2) groups of students of fifth semester: group one called control, which has not assigned any experimental condition and two so-called Group experimental group that interacts with a didactic proposal for meaningful learning. Students are characterized by having ages between 18 and 30 years.

In the understanding of Hernandez and Baptista (1997) [11], a quasi-experimental design, is defined as a kind of empirical study that lacks some of the usual features of experimentation, where the initial equivalence of the experimental groups is not secured and control. There is no inclusion criteria; in this case the characteristics of the environment and the variables involved are hardly controlled in its entirety.

In this research subjects are not assigned at random, were already formed before the experiment, which means they are intact groups, in this case are groups set up by the management of the Corporation's Industrial Engineering program University of the CORHUILA Huila.

The analysis of information thrown by applied instruments consisted of linking the dependent and independent variables to determine the significance level of academic achievement and relationship between these. The independent Variable corresponds to the didactic proposal for teaching of basic concepts of networks and management of algorithms in the resolution of problems of application of the route cuts in the context of networks, using meaningful learning. The dependent Variable refers to the achievement reached by the students measured through the results of a test theoretical and practical kind of the theme of the course.

The design of the pretest consists of 5 questions, allowing you to make an idea about the field of optimization in networks with a real situation.
Table 4 Analysis of the posttest means Posttest

\begin{tabular}{llllll}
\hline Groups & Median & $\mathrm{N}$ & Dev & Min & Max \\
\hline $\begin{array}{l}\text { Without } \\
\text { meaningful } \\
\text { learning } \\
\text { strategy }\end{array}$ & 1.97 & 34 & 1.34 & 0 & 4 \\
\hline $\begin{array}{l}\text { With } \\
\text { meaningful } \\
\text { learning } \\
\text { strategy }\end{array}$ & 4.24 & 34 & 0.89 & 1 & 5 \\
\hline Total & 3.10 & 68 & 1.60 & 0 & 5 \\
\hline
\end{tabular}

The questions involve modelling through a network connections between cities and their respective distances (origin and destination), ten going note that should use Dijkstra's algorithm or accumulated paths tree to determine the shorter of a city routes to other. Likewise each student should develop the problem with the help of computer programs Wing QSB and Solver of Excel the estimated time for its development was 110 minutes.

This test was endorsed by professional experts, as a group of students from eight (VIII) semester was taken with a characteristic in common; have taken and passed the subject of operations research for greater strength. Recommendations as to the content of the test not emerged in the development of this activity, developed smoothly.

\section{Results and Discussion}

The results were statistically organized in computer software Statistical Product and Service Solutions (SPSS) through the Kologorov-Smirnov test, data from pretest and posttest of each group, from a continuous normal distribution. This is considered the maximum level of significance of 0.05 [12]. Table 3 shows an analysis of means of the pretest of the corresponding to groups 1 and 2, which shows great similarity in the averages with values of 0.76 for the group control and 0.68 for the experimental group. Likewise, the dispersion is low in groups with values of standard deviation which does not exceed the unit.

The above shows that the results are homogeneous and that none of the students of Group One (no meaningful learning strategy) and Group Two (with meaningful learning strategy), knew the two correct answers and that students they have great difficulties in working the theme. In Table 4 the values of the averages of the posttest are shown, where the group with meaningful learning strategy presents a high average, with a value greater than 4 units, thus constituting a passing result in a satisfactory manner in contrast with the control group which fails to overcome his average the two correct answers. 


\section{TECCIENCIA}



Figure 1 Stockings for the pretest box diagram

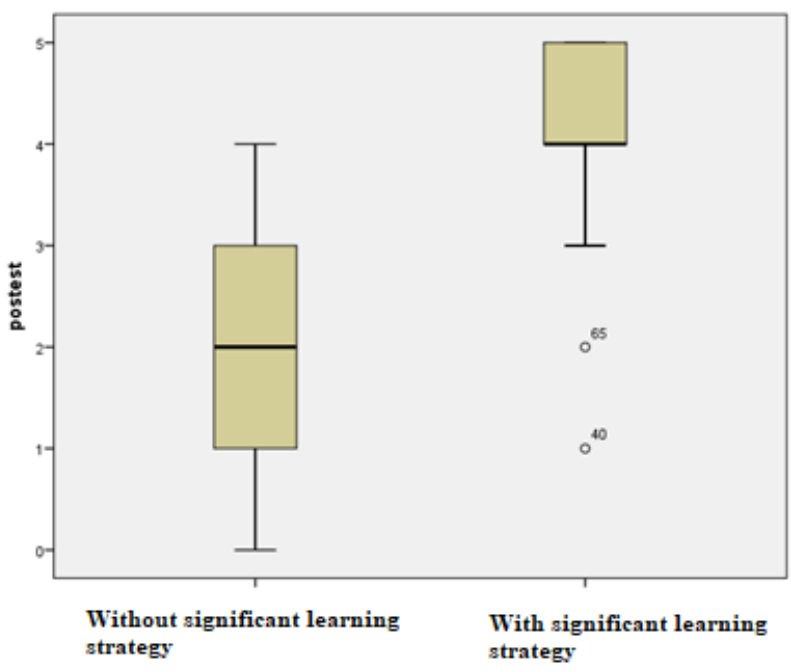

Figure 2 Stockings for the posttest box diagram

Taking into account the deviation, it is less available in Group 2, with meaningful learning with a standard deviation of 0.89 , reflected similarity in the results of students in that group. In Group 1, without meaningful learning strategy, the dispersion is of 1.337 , presents higher variability than in Group 2, due to meaningful differences in the results of students in that group.

To evaluate the distribution of the quantitative variable in the different groups being compared in this study graphically, a diagram of boxes is developed for having a visual approximation of the means of the pretest and posttest.
Table 5 Pretest ANOVA factors

\begin{tabular}{llllll}
\hline & $\begin{array}{l}\text { Square } \\
\text { addition }\end{array}$ & gl & $\begin{array}{l}\text { Quadratic } \\
\text { median }\end{array}$ & F & Sig. \\
\hline $\begin{array}{l}\text { Inter- } \\
\text { groups }\end{array}$ & 0.132 & 1 & 0.132 & 0.277 & $\begin{array}{l}0.60 \\
1\end{array}$ \\
\hline $\begin{array}{l}\text { Intra- } \\
\text { groups }\end{array}$ & 31.559 & 66 & 0.478 & & \\
\hline Total & 31.691 & 67 & & & \\
\hline
\end{tabular}

Table 6 Posttest ANOVA factors

\begin{tabular}{llllll}
\hline & $\begin{array}{l}\text { Square } \\
\text { addition }\end{array}$ & gl & $\begin{array}{l}\text { Quadratic } \\
\text { median }\end{array}$ & F & Sig. \\
\hline $\begin{array}{l}\text { Inter- } \\
\text { groups }\end{array}$ & 87.191 & 1 & 87.191 & 67.6 & 0.0 \\
\hline $\begin{array}{l}\text { Intra- } \\
\text { groups }\end{array}$ & 85.088 & 66 & 1.289 & & \\
\hline Total & 172.279 & 67 & & & \\
\hline
\end{tabular}

Figure 1 shows that the pretest box diagram can show that most of the results of the two groups are in the quartiles 1 and 2, shows that students of Group One (no meaningful learning strategy) and Two (with a strategy meaningful learning) depart from pre equal knowledge, i.e., they do not possess strong foundations on the concept of network and short route.

In Figure 2 the posttest box diagram shows that most of the results are among the quartiles 2 and 3 in the Group 1 (without meaningful learning strategy), presents improvements with respect to the results of the pretest, but without submit passing results, since the values did not reach the 3 correct answers. In the group with meaningful learning strategy, values of treatment significantly increased at the beginning, located mostly in the quartile 4 , with four or five correct answers. However, arose some outliers in the first two quartiles.

The statistical value $\mathrm{F}$ of 0.277 analyzed in the ANOVA statistical test in relation to the pretest (Table 5), with its corresponding level of significance observed 0.601 (greater than 0.05), approves the null hypothesis that supports the meaningful equality of means. And while stockings in groups 1 and 2 are different, such a difference is not significant (statistical equality of the $95 \%$ confidence). The statistical analysis of the ANOVA of the posttest (Table 6), shows that $F=67.63$ with a critical level of 0.000 , which rejects the null hypothesis of equality of means, outlines the results of one of the groups are significantly different.

Table 7 shows the value of the statistic of Levene (1.338) in the pretest and (11.575) for the posttest, and the degrees of freedom in its distribution $(\mathrm{df} 1=1, \mathrm{df} 2=66$ pretest $),(\mathrm{df} 1=$ $1, \mathrm{df} 2=66$ posttest) respectively. 


\section{TECCIENCIA}

Table 7 Levene statistic test results.

\begin{tabular}{lcccc}
\hline & $\begin{array}{c}\text { Levene } \\
\text { Statistic }\end{array}$ & gl1 & gl2 & Sig. \\
\hline Pretest & 1.338 & 1 & 66 & 0.252 \\
\hline Posttest & 11.575 & 1 & 66 & 0.001 \\
\hline
\end{tabular}

The critical level or probability of obtaining values as obtained or lower in the Levene test are 0.252 pretest and 0.001 posttest. This allows to define the critical level is greater than 0.05 in the pretest, which must reject the hypothesis of equality of variances and the post test is less than 0.05 .

Thus it is possible to conclude that rejecting the null hypothesis of equal variances identified greater variability on the results of academic achievement with a didactic proposal in meaningful learning in the teaching of basic concepts of networks and management of algorithms in the resolution of problems of application of the route cuts in the context of networking.

The motivation of the student with the integration of teaching resources was determined in the observation made and collected through the diaries of field of work of the students in each of the years when they developed the algorithms through the WinQSB and the Microsoft Excel Solver add-on (Table 8).

It is noticeable that the number of students in the group with meaningful learning strategy is substantially high, surpassing $88 \%$ of the sample size in aspects of responsibility with the submission of exercises, creativity, commitment and interest, as well as class performance

Hence, one of the essential aspects of meaningful learning is the change of attitude by the activities to develop, students enjoy what they learn, feels comfortable, deliver timely results and feel satisfied of your experience educational. At the same time this strategy led to a space for questions, second opinions made contributions and socialization of the different algorithms, highlighting dedication and familiarity with the issues.

\section{Conclusions}

The statistical analysis provided satisfactory evidence to assert that there are representative differences in academic achievement in the construction of the concept of network and algorithm of the short route in the context of operations research.
Table 8 Participation of students in the group with meaningful learning strategy.

\begin{tabular}{lc}
\hline Analysis category & $\begin{array}{l}\text { Number of students } \\
\text { in the experimental } \\
\text { group }\end{array}$ \\
\hline $\begin{array}{l}\text { Responsibility with the } \\
\text { submission of exercises }\end{array}$ & 33 \\
\hline Creativity & 30 \\
\hline Commitment and interest & 31 \\
\hline Class performance & 30 \\
\hline
\end{tabular}

This process begins from a teaching strategy with meaningful learning in university students in contrast with the group without teaching strategy with meaningful learning.

These results were obtained with an average for the Group 2 (with meaningful learning strategy), being the highest and when compared with average thrown the pretest, you have an increase of 3.56 .

If we return at this point to the importance attributed to the meaningful learning to provide effective theoretical elements, splitting always of prior knowledge, of what the student knows, is essential to take the starting point position in a learning process. Based on the developed experience is meaning to the concept of network built and applied to real contexts. The student experience that their preconceptions and experiences are valid and it is natural that these are transforming to a more elaborate [13]

In the process of students' learning of the development of Dijkstra's algorithm with their respective systematization and accumulated paths algorithms they exercised the representation of networks used broadly in areas such as production, distribution, project planning, location of facilities, resources and financial planning, management, comprehensive management, areas which are essential to the formation of industrial engineers. To achieve the significance of this issue it is necessary to provide the kind of real elements such as readings of products of research, analysis of real cases consistent with the networks, starting from the knowledge of the student.

It is worth emphasizing the importance of a proper methodological approach in the concept of networks implying a uniformity in the objectives of the course and the human resource that points to the guidelines of the institution and the program in real contexts in engineering that they require the transition from abstract to something applied. 


\section{TECCIENCIA}

\section{Acknowledgements}

Students of CORHUILA, academic executives of CORHUILA.

\section{References}

[1] H. Moskowitz y F. V. Otalvaro, «Planeación de la asignatura programación i en un programa de ingeniería de sistemas a partir de la teoría del aprendizaje significativo.,» Revista Educación en Ingeniería, pp. 102-114, 2011.

[2] H. Moskowitz y F. V. Otalvaro, Investigación de operaciones, Prentice Hall, 1982.

[3] R. S. Campión, F. Navaridas Nalda y L. A. A. Andía Celaya, «Las percepciones de los directivos de centros escolares sobre el uso y el valor de las TIC para el cambio e innovación educativa,» Universidad de Navarra, vol. 30, pp. 145-174, Marzo 2016.

[4] A. A. Sánchez Rosal, «Estrategias didácticas para el aprendizaje de los contenidos de trigonometría empleando las TICs,» Revista Electrónica de Tecnología Educativa, n³ 31, pp. 1-19, 2010.

[5] F. Díez Marentes, «Cambios emergentes en las concepciones y prácticas educativas de docentes que implementan la modalidad Blended Learning,» Innovate 330, 2016. [En línea]. Available: https:/conectate.uniandes.edu.co/contenido/innovate_330/doc/Innovate-330.pdf.

[6] D. C. Argüelles Pabón y N. Nagles García, Estrategias para promover proceso de aprendizaje autónomo, Bogotá: Universidad EAN, 2010.

[7] D. P. Ausubel, The psychology of meaningful verbal learning, New York, 1963.

[8] G. A. Tizón Freiría, Las TIC en la Educación, Lulupress, 2008, p 160 .

[9] J. Ametller, J. Leach y P. Scott, «Using perspectives on subject learning to inform the design of subject teaching: an example from science education,» The Curriculum Journal, pp. 479-492, 2008.

[10] M. Apostolos, K. Aikaterini y . T. Thrasyvoulos, «Impact of online flexible games on students' attitude towards mathematics,» Educational Technology Research and Development, vol. 65, p 1451-1470, 2017.

[11] R. Hernández Sampieri, C. Fernández Collado y P. Baptista Lucio, Metodologia de la Investigacion, Mcgraw-Hill, 2014.

[12] M. J. Marques Dos Santos, Estadistica Basica Un enfoque no parametrico, México: Universidad Nacional Autónoma de México, 2007.

[13] M. L. Rodríguez Palmero, «La Teoría del Aprendizaje Significativo,» Proc. of the First Int. Conference on Concept Mapping, Pamplona, 2004.

[14] L. Crawford, K. N. Higgins, J. N. Huscroft-D’ Angelo y H. Lindsay , «Students' use of electronic support tools in mathematics,»
Educational Technology Research and Development, p. 1163-1182, 2016.

[15] R. Peley, R. Morillo y E. Castro, «Las estrategias instruccionales y el logro de aprendizajes significativos,» Omnia, vol. 13, $\mathrm{n}^{\circ} 2$, pp. 5675,2007 